\title{
Mothers, Environment, and Ontogeny Affect Cognition
}

\author{
Christophe Boesch
}

Department of Primatology, Max Planck Institute of Evolutionary Anthropology

Corresponding author (Email: boesch@eva.mpg.de)

Citation - Boesch, C. (2020). Mothers, environment, and ontogeny affect cognition. Animal Behavior and Cognition, 7(3), 474-489. doi: https://doi.org/10.26451/abc.07.03.13.2020

\begin{abstract}
The book "Folk Physics for Apes" remains a fascinating book about the way one captive peer-group of chimpanzees understand the world in which they grew. However, the very special living conditions these seven individuals faced prevent any generalizations to the species level. Moreover, numerous recent studies have revolutionized our understanding of brain development and cognitive abilities in documenting much higher brain plasticity and important variations in the level of cognitive abilities in many species, including humans. Environmental enrichment and physical practice can lead to impressive improvements in the performance of many different cognitive abilities during the lifetime and these changes are observed within relative short periods of time and proportional to the environmental improvements or the level of physical practices. This much higher plasticity of cognitive abilities requires a new way of thinking in comparative cognitive studies incorporating a multiconditions multi-populations perspective before reaching conclusions that could be generalized to the species level. In that sense, "Folk Physics for Apes" is only one of the many pieces needed before we can draw conclusions about potential differences between chimpanzees and humans.
\end{abstract}

Keywords - Chimpanzee, Cognition, Mother, Environment, Ontogeny

Daniel Povinelli's book "Folk Physics for Apes" remains a wonderful example of the challenges faced when attempting cognitive studies with a comparative approach. Taking position in the essential discussion about "what is cognition?," he questioned some so-called generous interpretations of cognitive abilities in chimpanzees, while basing his whole argument on one specific definition of cognition. Truthful to his comparative psychology discipline, he seemed to adopt a one cognition approach whereby all individuals of a same species develop very similar cognitive abilities independent of their living conditions. Consequently, for Daniel Povinelli, the few captive individuals he studied revealed the fullblown cognition spectrum of the species. In "Folk Physics for Apes," Daniel Povinelli genuinely explained at some length how he shaped the group of chimpanzees to best fit his plans: for this, he selected five hand-reared orphan infants and two infants separated from their mother after the first year of life, then he placed them together in a captive setting, i.e., a perfect peer group! To make the experimental approach, he envisioned, more practical and easy, he had them living in some specific quarters all optimized to implement his approach (see Figure 1). As long as one agrees with the predictions of the "One Cognition" approach, his book is a fascinating account of the cognition of the "Chimpanzee."

The obvious question is whether the basic assumption of the "One Cognition" approach is supported. Did Povinelli report about "Chimpanzee cognition" or only about the cognition of "seven captive orphan chimpanzees in a peer group?" Can the living conditions provided to these seven chimpanzees be considered as representative for the species "chimpanzee?" Povinelli (2000) justifies his choice of using only seven mainly hand-raised similar-aged young chimpanzees with these words: 
If it is to be valid, any such project requires normal, healthy animals, who display a full suite of chimpanzee behaviors (from the relaxed bouts of social grooming, to the deafening, late-afternoon pant-hoots). In short, a valid project requires chimpanzees who have been raised in a comfortable, spacious setting that has drawn out their normal social and cognitive abilities. Ironically, one incidental consequence of raising captive chimpanzees in this kind of captive setting is that they typically wind up far more healthy than their distant cousins in the wild-animals who are frequently racked by infections, unhealed wounds, and parasitic infestations. (p. 15)

\section{Figure 1}

The Living Quarters Created for the Seven Young Chimpanzees used by Daniel Povinelli for his Series of Experiments to Understand the "Chimpanzee Mental States"

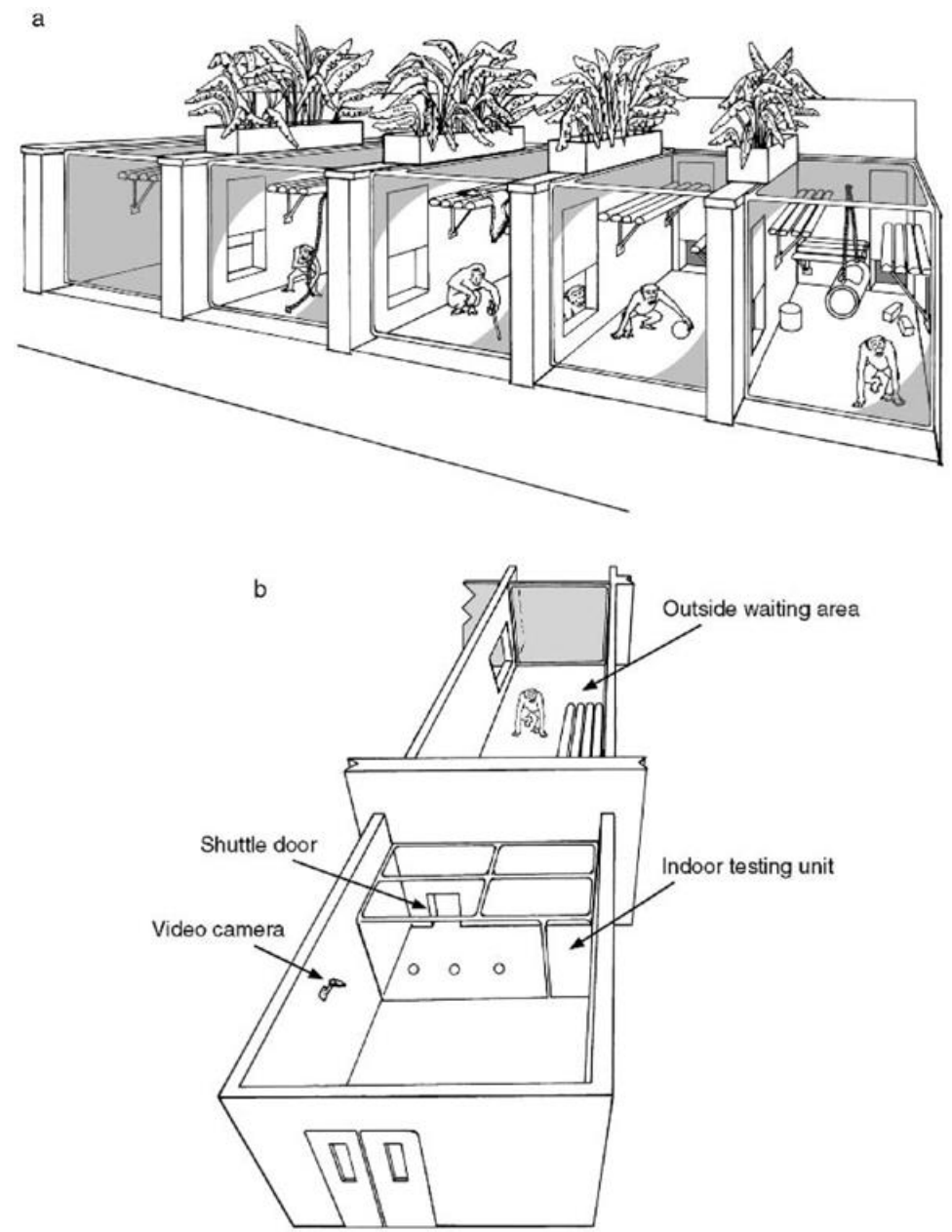

Note. This illustration shows the environmental conditions provided to the individuals for their life (from Figure 2.2 in Povinelli, Folks Physics for Apes, 2000).

He summarized his approach by saying "rear a cohort of chimpanzees together, while simultaneously exposing them to human culture" (Povinelli, 2000, p. 18). Can hand-raised captive peergroup life be considered as representative for wild-living chimpanzees? Was Povinelli ironical when he suggested that captive individuals are healthier than wild counterparts, or did he simply ignore all the 
evidence that captive chimpanzees are showing important signs of distress, anxieties and trauma (Birkett \& Newton-Fisher, 2011; Clay \& de Waal, 2013; Leeuwen et al., 2014)? When addressing this question at the end of his book, Povinelli (2000) answers by saying that the captive chimpanzees demonstrate a lot of very elaborate cognitive abilities and many very similar to wild individuals, suggesting that, thanks to the human contacts, the captive individuals may actually possess "a more elaborate folks physics than their counterparts in the wild" (p. 327).

\section{The Ontogeny of Cognition is a Complex Developmental Process}

If, however, we envision that cognition, the sum of all cognitive abilities present in an individual, is not only about genetic determinism, but rather that those cognitive abilities develop as individuals grow and interact with their environment, then we need to realize that studying cognition requires an understanding of the dynamic of the different influences that, during ontogeny, contributes to adult cognition. We need to think of cognition not simply in terms of genetic determination, but adopt a multifactorial approach including all aspects of the ecology that affect the development of cognition in an individual. If, to some, the classic debate between "Nature versus Nurture" has been resolved, as most scholars agree that genotype and ecology contribute to the development of cognition, some important gaps in our knowledge persist to understanding the relative amplitude of the effects of genotype and ecology on cognition (see Figure 2). In the best-studied species on Earth, humans, detailed study of the genetic and environmental effects on intelligence reveal that they are not always independent; sometimes gene influences might depend on the environment or they might act indirectly through correlated environments (Gray \& Thompson, 2004). In human twin studies, it was proposed that $40 \%$ of the variability in general cognitive ability could be attributed to genetic factors; although this effect is highly heterogeneous depending on the part of the brain considered (heritability ranges from 0 to $100 \%$, Gray \& Thompson, 2004).

Figure 2

The Nature-Nurture Debate Still Has Some Important Gaps.

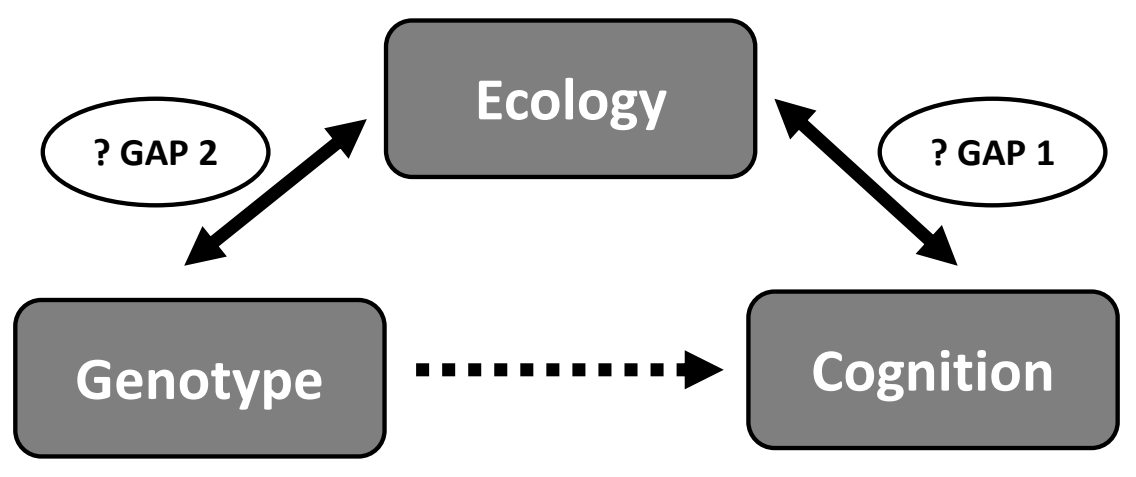

Note. Most scientists agree that the genotype alone does not select for cognition, and that the ecology plays a role in it. However, the data are still missing to quantify the relative contribution of the ecology on the emergence of cognitive abilities in different species (gap 1), with some psychologists sometimes totally neglecting those influences, while behavioral ecologists argue for an important contribution of ecology. At the same time, neuroscientists have provided new data with environmental enrichment studies showing that the ecology has some strong impacts on the formation of brain structures and volumes (gap 2), that have been shown to influence the cognitive abilities of the individuals (see more in the text and Table 1). 
Furthermore, if we think that cognition develops as individuals grow and interact with their environment; then we should expect that the same cognitive ability may provide different benefits under different environmental conditions. For example, spatial abilities will be more beneficial to wide-ranging species than smaller-ranging ones, and even more so to individuals from populations living in lowvisibility environments, where orientation and finding food will be more challenging, than for individuals living in open environments (e.g., Janmaat et al., 2016; Rosati et al., 2014; see Table 1 below). Similarly, long-term memory will be more beneficial to food-storing species rather than to non-food-storing ones and more so for species storing large amount of items in areas they do not normally visit when foraging (see Healy et al., 2008; Pravosudov \& Roth, 2013; Smulders et al., 2010). At the same time, social skills would be more beneficial for species living in large and complex social groups rather than solitary or small-group species (Noonan et al., 2014; Olser et al., 2012; Quallo et al., 2009). Fission-fusion social grouping has been proposed to be one of these types of social complexity selecting for refined social knowledge and understanding (Aureli et al., 2008). In other words, we should expect different combinations of cognitive abilities to be selected for in populations facing different environmental conditions. In addition, environmental conditions are not stable over the lifetime of an individual, and they show important variations, seasonal or across years, making flexible learning of some specific cognitive abilities beneficial (see Table 1 below). Thus, individuals in the wild have to adapt to new environmental conditions and do so quickly enough to survive when facing unstable conditions. Many new studies have demonstrated that such flexibility is observed both in brain structures and in cognitive performances (Healy et al., 2008; Smulders et al., 2010, see below Table 1). In other words, cognition, the sum of all cognitive abilities present in an individual, will vary across individuals within one species and across different periods of its life. This all makes cross-species comparison a complex undertaking.

The last 20 years has seen a burgeoning of new studies analyzing the impact of environmental enrichment on the development of brain structures and cognition (see Table 1). These studies have revolutionized our way of understanding brain plasticity, as classically, the brain was considered as a rather fixed organ once the individual was mature. Recent works all show that the brain possesses much more plasticity than thought and that this plasticity is observed during all stages of life. In addition, many careful studies have shown how such changes in brain structures and volumes result in changes in cognitive abilities. In Table 1, I summarize some of the most striking studies showing such effects when considering six broad aspects of ecology. Many more works could be cited in this very active neurological field and readers interested in this field should consult some detailed reviews (e.g., Gelfo et al., 2018; May, 2011; Mora et al., 2007; van Praag et al., 2000; Voss et al., 2013). The main conclusion of Table 1 is that all studies considering improvements in the six ecological factors resulted in important changes in different regions of the brain and many of them showed clear effects on cognitive performance in all species considered.

First, in all mammals, the mother is, for an extended period, the prime social partner of every infant. In chimpanzees, an infant suckles and is carried by the mother for the first five years of life and remains associated permanently with her until he is 10, at which time, as an adolescent, he is still seen 75\% of the time with her until reaching adulthood (Boesch \& Boesch-Achermann, 2000; Goodall, 1968, 1986). Table 1 details some of the negative impacts that maternal deprivation has both on the development of the brain and on cognitive abilities. Since all the chimpanzees tested by Povinelli in his studies were maternally deprived for different lengths of time, these data are especially relevant (see also Bogart et al., 2014, and Table 1).

Second, as we see in Table 1, many studies have documented the impressive impacts of physical exercise and of complex environment on the development of many brain regions as well as on the improvement of cognitive abilities (see review, Erickson et al., 2009; van Praag, 2009; Voss et al., 2013). It is important to note that these effects are proportional to the amount of exercise as well as the level of complexity of the environment and that these effects can be observed after very short intervals of time, such as after a few days of exercise (van Praag, 2009; Table 1, this paper). The importance of the environment on cognition is supported by several meta-analyses that show that brain size is mainly 
explained by ecological factors rather than social ones (DeCasien et al., 2017; González-Forero \& Gardner, 2018; Rosati, 2017).

Studies comparing wild populations support such conclusions; For example, important differences have been found in the hippocampal volumes and spatial memories of populations of chickadees living under different environmental conditions (Table 1). More specifically, wild capuchin monkeys consistently and immediately selected functional tools, outperforming captive capuchin monkeys tested in tool tasks (Schrauf et al., 2008; Visalberghi et al., 2009, Table 1). The authors concluded "in light of these findings, we must reconsider the manner in which we evaluate cognition in captive primates" (Visalberghi et al., 2009, p. 215).

Since it is known that the different brain regions function as a "network", in the sense that many different regions of the brain are activated to perform the same task, while a same region of the brain can be activated for different tasks (Anderson, 2010, 2016; Anderson et al., 2013), the amplitude of the effects on cognition of brain structural changes resulting from environmental enrichment is likely to be underestimated. This has led to new studies on the connectivity within the brain of different regions (Mars et al., 2013; Neubert et al., 2015; Sallet et al., 2013) illustrating the complexity of the functioning of the brain and of the potential pleiotropic effects of the environment. This was illustrated in a study showing that cognitive training not only improved cognitive performance on the trained task, but also resulted in improvement in cognitive tasks entirely different from the intelligence test itself (Jaeggi et al., 2008).

An important aspect in the discussion about the effects of ecology on cognition is to remember that all experiments cited in Table 1, were done in captive settings and thus, the environmental enrichment was limited. For example, much of the enrichment provided to the rats and mice, and that produce spectacular improvements, was limited to providing a running wheel, some tubes and boxes (van Praag, 2009), which remains a very simple environment compared to the complexity experienced in nature. This circumstance most likely results in a further underestimation of the amplitude of the effects of ecology on the development of brain plasticity and cognition (Gelfo et al., 2018; Mora et al., 2007).

So when thinking about cognition, we need to include not only genetic determinism but also different aspects of the ecology within an ontogenetic perspective, as all contribute to shape the cognitive abilities an individual will acquire. Whenever we read a study about cognitive abilities, one needs to ask: what were the experiences the subjects had during their ontogeny? What were the environmental and social conditions they faced during their life? This way of thinking has too often been ignored in experimental psychology, despite the fact that field observers provided extensive evidence for the interconnection of ecology, predation pressure, and sociology on the development of cognition in wild primates (Barrett et al., 2007; Boesch \& Boesch-Achermann, 2000; Cheney \& Seyfarth, 1990, 2007) and a meta-analysis of experimental studies concurred with this (Thornton \& Lukas, 2012). This broader perspective is now strongly supported by the work of neuroscientists on environmental enrichment.

\section{What is the Value of Povinelli's Chimpanzee Peer Group Study?}

I totally agree with Tomasello and Call (2008) in that captive studies of chimpanzees have revealed many sophisticated cognitive abilities. Chimpanzees are our closest living relatives, and this evolutionary proximity predicts many cognitive similarities with humans. The fact that captive chimpanzees are intelligent does not imply that they are representative for the cognitive achievements of their wild counterparts (see below, Table 3). The suggestion of some experimental psychologists is that field observations are essential to know what an animal species is capable of doing but that, without wellcontrolled experiments, it is impossible to draw any conclusions about the underlying cognitive mechanisms (Povinelli, 2000, 2012; Tomasello \& Call, 1997, 2008). This perfectly logical argument, however, works only if the subjects used in the experiments had the same experience of life as the wild counterparts. Otherwise, it becomes extremely difficult to know whether the results found are due to differences in the cognitive abilities of the individuals or due to different living conditions and experiences (Boesch, 2007; Leavens et al., 2019). 
Table 1

Summary of Some of the Data Showing the Different Effects of the Socio-Ecological Environment on the Development of Brain Structures and Cognition

\begin{tabular}{|c|c|c|c|c|}
\hline Factor & Effects on Brain Structure & References & Cognitive Effects & References \\
\hline $\begin{array}{l}\text { Maternal } \\
\text { Deprivation }\end{array}$ & $\begin{array}{l}\text { Growing with maternal deprivation early in life affects many } \\
\text { areas of the brain: } \\
\text { - Irreversible reduction of dentate gyrus granule cell number and } \\
\text { density in adult female rats, as well as dentate gyrus neurons } \\
\text { altered in dendritic arrangement } \\
\text { - Life-long hypothalamic dysfunction in rhesus monkeys } \\
\text { - Lack of a secure attachment relationship in early years has } \\
\text { detrimental long-term effects on health in rhesus monkeys } \\
\text { - Long-term alteration in hypothalamic-pituitary-adrenal axis } \\
\text { activity, disturbance of auditory information processing and } \\
\text { neurochemical changes in adult rat brain } \\
\text { - Life-long decrease of white-to-grey matter volume, in cortical } \\
\text { folding and larger grey matter within cortical folds in nursery- } \\
\text { reared compared to mother-reared chimpanzees }\end{array}$ & $\begin{array}{l}\text { Bogart et al., } \\
2014 \text {; } \\
\text { Conti et al., } \\
\text { 2012; } \\
\text { Feng et al., } \\
2011 \text {; } \\
\text { Oomen et al., } \\
2011\end{array}$ & $\begin{array}{l}\text { Growing with maternal deprivation early in life leads to: } \\
\text { - Deficits in association, social responsiveness, learning } \\
\text { abilities, exploration, communication in primates } \\
\text { - Long-lasting increased cortisol response to stress with } \\
\text { persistence of stereotypical behaviors after } 3 \text { yrs of normal } \\
\text { social life in rhesus monkeys } \\
\text { - Impairment in spatial learning ability and reduced spatial } \\
\text { working memory in adult rats } \\
\text { - Shorter play bouts with more aggression outcomes in } \\
\text { orphan chimpanzees than mother-reared ones } \\
\text { - Impaired spatial learning in adulthood in mammals }\end{array}$ & $\begin{array}{l}\text { Feng et al., } \\
2011 ; \text { Garner et } \\
\text { al., 2007; } \\
\text { Leeuwen et al., } \\
2014 ; \\
\text { Novak \& } \\
\text { Harlow, 1975; } \\
\text { Pravosudov \& } \\
\text { Omanksa, 2005; } \\
\text { Suomi \& } \\
\text { Harlow, } 1972\end{array}$ \\
\hline $\begin{array}{l}\text { General } \\
\text { Ecology }\end{array}$ & $\begin{array}{l}\text { - In humans, ecology contributes to } 60 \% \text { of brain size increases, } \\
\text { while cooperation accounts for } 30 \% \text { of brain size decreases. } \\
\text { - Chimpanzees hippocampus is less asymmetrical and larger } \\
\text { with more connectivity with other brain regions than in } \\
\text { bonobos, possibly due to larger dependence on patchy fruit } \\
\text { resources within large territories in chimpanzees. } \\
\text { - Frugivorous primates possess enlarged brain size compared to } \\
\text { folivorous ones, presumably as a result from larger spatial } \\
\text { information storage and retrieval due to higher cognitive } \\
\text { demands of extractive foraging of fruits and seeds. }\end{array}$ & $\begin{array}{l}\text { González- } \\
\text { Forero \& } \\
\text { Gardner, } \\
2018, \\
\text { Hopkins et al., } \\
2009, \\
\\
\text { DeCasien et } \\
\text { al., } 2017\end{array}$ & $\begin{array}{l}\text { - Population of birds of the same species experiencing harder } \\
\text { winter possess larger hippocampal volume, higher number } \\
\text { of hippocampal neurons, and neurogenesis rate and have } \\
\text { better spatial memory performances. } \\
\text { - Golden lion tamarins that range far to feed on insects and } \\
\text { patchy fruits show more accurate spatial memory over } \\
\text { longer time intervals than Wied's marmosets that are } \\
\text { obligate gummivores in small home ranges. } \\
\text { - Lemurs with more complex diets show more sophisticated } \\
\text { memory and inhibitory control capacities than more } \\
\text { folivorous species. }\end{array}$ & $\begin{array}{l}\text { Pravosudov \& } \\
\text { Roth, 2013, } \\
\text { Rosati , } 2017\end{array}$ \\
\hline $\begin{array}{l}\text { Physical } \\
\text { Training }\end{array}$ & $\begin{array}{l}\text { - In humans, expert pianists possess higher gray matter density } \\
\text { and higher white matter integrity in primary sensorimotor } \\
\text { cortex and right cerebellum than novices. } \\
\text { - Jugglers show bilateral expansion of grey matter in mid- } \\
\text { temporal area and left posterior intraparietal sulcus. } \\
\text { - Handballers possess increased grey matter volume in the right } \\
\text { primary/secondary motor, bilateral cingulate motor area and left } \\
\text { intraparietal sulcus. } \\
\text { - Skilled golf players show larger gray matter in fronto-parietal } \\
\text { network including premotor and parietal areas. } \\
\text { - In rodents, dentate gyrus neurons of the hippocampus can be } \\
\text { doubled or tripled with exercise. } \\
\text { - Brain-derived neurotropic factor that supports neural survival, }\end{array}$ & $\begin{array}{l}\text { Han et al., } \\
2009, \\
\text { Draganski et } \\
\text { al., 2004, } \\
\text { Haenggi et al., } \\
2015 \\
\text { Jaencke et al., } \\
2009, \\
\text { Voss et al., } \\
2013\end{array}$ & $\begin{array}{l}\text { Physical training in captive setting leads to: } \\
\text { - Enhance hippocampus-dependent spatial memory and } \\
\text { pattern discrimination and the more so with harder } \\
\text { cognitive tasks in rodents } \\
\text { - Improves passive avoidance learning, spatial pattern } \\
\text { separation and novel object recognition in primates } \\
\text { - Faster and more accurate spatial short-term memory } \\
\text { performance and spatial learning performance in adult } \\
\text { humans } \\
\text { - Jogging and long jump are associated with cognitive } \\
\text { information process and inhibitory control in humans. } \\
\text { - In elderly humans, those who participated in high levels of } \\
\text { exercise showed less cognitive decline in the following } 5\end{array}$ & $\begin{array}{l}\text { Voss et al., } \\
2013 \text {; van } \\
\text { Praag et al., } \\
2000, \\
\text { Erickson et al., } \\
2009 \\
\text { Esmaeilzadeh et } \\
\text { al., 2018, }\end{array}$ \\
\hline
\end{tabular}




\begin{tabular}{|c|c|c|c|c|}
\hline & $\begin{array}{l}\text { growth and synaptic plasticity increase activity in cerebellum } \\
\text { and hippocampus with physical activity. }\end{array}$ & & years. & $\begin{array}{l}\text { Middleton et al., } \\
2008\end{array}$ \\
\hline $\begin{array}{l}\text { Environmental } \\
\text { Complexity / } \\
\text { Enrichment }\end{array}$ & $\begin{array}{l}\text { Environmental enrichment experience in captivity reveals: } \\
\text { - In rodents and primates, more complex environment results in } \\
\text { increased number and volume of white and grey cells, in the } \\
\text { number of synaptic connections, enhanced cell survival, } \\
\text { increased neurogenesis, increase dentritic branching, and } \\
\text { improved synaptogenesis and neurotransmitter expression } \\
\text { - Enhanced length and complexity of dendritic tree, increase } \\
\text { dendritic spine density and synaptic protein levels in } \\
\text { hippocampus and prefrontal cortex in adult marmosets }\end{array}$ & $\begin{array}{l}\text { van Praag et } \\
\text { al., } 2000, \\
\text { Mora et al., } \\
2007, \text { May, } \\
2011, \text { Voss et } \\
\text { al., } 2013, \\
\text { Gelfo et al., } \\
2018, \\
\text { Kozorovitskie } \\
\text { et al., } 2005\end{array}$ & $\begin{array}{l}\text { Across taxa, decision-making, spatial and vocal learning and } \\
\text { discrimination are environment condition dependent. } \\
\text { - Population of chickadees in harsher conditions exhibited } \\
\text { faster problem solving, lower incidence of neophobic } \\
\text { behaviors and better spatial memory compared to } \\
\text { populations in milder conditions. } \\
\text { - In salmon, environmental enrichment enhanced the } \\
\text { forebrain expression of NeuroD1 mRNA and improved } \\
\text { learning ability assessed in a spatial task. } \\
\text { - In human twin studies, hippocampal volume shows lower } \\
\text { heritability than the frontal lobe volumes, indicating strong } \\
\text { environmental influence on hippocampal development and } \\
\text { consequently spatial abilities. }\end{array}$ & $\begin{array}{l}\text { Buchanan et al., } \\
2014, \\
\text { Salvanes et al., } \\
2013 \text {, } \\
\text { Peper et al., } \\
2007\end{array}$ \\
\hline $\begin{array}{l}\text { Tool and } \\
\text { Technical } \\
\text { Innovation }\end{array}$ & $\begin{array}{l}\text { - Macaques trained to use tools had increased gray matter in } \\
\text { right superior temporal sulcus, right second somatosensory } \\
\text { area and right intraparietal sulcus, with less effect on the left. } \\
17 \% \text { increase within few weeks } \\
\text { - Chimpanzees' tool use result in marked leftward asymmetries } \\
\text { in relative white matter of the perisylvian cortical regions, } \\
\text { - Tool-using birds have more folded cerebellar cortex but not a } \\
\text { larger cerebellum than non-tool-using species. }\end{array}$ & $\begin{array}{l}\text { Quallo et al., } \\
2009, \\
\text { Cantalupo et } \\
\text { al., } 2009 \text {, } \\
\text { Iwaniuk et al., } \\
2009\end{array}$ & $\begin{array}{l}\text { - In primates and birds, absolute and relative brain size } \\
\text { correlates strongly with tool use innovation and only } \\
\text { weakly with non-technical innovation. } \\
\text { - In macaques, tool use training enhances performance in } \\
\text { understanding spatial relations, causal cognition, } \\
\text { numerosity and causality. } \\
\text { - Wild capuchin monkeys consistently and immediately } \\
\text { selected functional tools, regardless of conditions, } \\
\text { outperforming captive capuchin monkeys tested in tool } \\
\text { tasks. }\end{array}$ & $\begin{array}{l}\text { Navarrete et al., } \\
\text { 2016, Lefebvre } \\
\text { et al., 2002, } \\
\text { Tia et al., 2018, } \\
\text { Schrauf et al., } \\
2008, \\
\text { Visalberghi et } \\
\text { al., } 2009\end{array}$ \\
\hline $\begin{array}{l}\text { Parental Socio- } \\
\text { economic } \\
\text { Status }\end{array}$ & $\begin{array}{l}\text { Growing up in low parental socioeconomic status in humans is } \\
\text { associated with: } \\
\text { - Smaller gray matter volume in bilateral hippocampi, middle } \\
\text { temporal gyri, left fusiform and right inferior occipito-temporal } \\
\text { gyri } \\
\text { - Lower cortical folding in anterior frontal regions } \\
\text { - Smaller cortical surface areas in number of regions supporting } \\
\text { language, reading, executive functions, memory and spatial } \\
\text { skills } \\
\text { - This last effect is proportionally larger among children from } \\
\text { lower income families than in higher income families. }\end{array}$ & $\begin{array}{l}\text { Hackmann \& } \\
\text { Farah, 2009, } \\
\text { Jednorog et } \\
\text { al., 2012, } \\
\text { Noble et al., } \\
2015\end{array}$ & $\begin{array}{l}\text { Lower parental socioeconomic status is associated in humans } \\
\text { with: } \\
\text { - Lower literacy and verbal skills } \\
\text { - Trends for lower memory and visuo-spatial processing } \\
\text { In chimpanzees, imitation training subjects show changes in } \\
\text { what matter integrity and frontoparieto-temporal connectivity } \\
\text { in the left hemisphere within the mirror system, which } \\
\text { facilitated complex imitation learning abilities. }\end{array}$ & $\begin{array}{l}\text { Hackmann \& } \\
\text { Farah, 2009, } \\
\text { Jednorog et al., } \\
2012, \\
\text { Pope et al., } \\
2018\end{array}$ \\
\hline
\end{tabular}

Note. It should be noted that, up to now, most of this work has been done with captive animals and therefore might still underestimate the amplitude of the effects of each factor when considering the higher complexity of the natural socio-ecology existing in nature. 
Table 2 summarizes some of the differences observed in human-chimpanzee comparisons when basing them on captive experiments, field experiments or field observations. Captive experiments have the potentially huge advantage to present similar procedures to both species, and in theory control for potential confounds that are suggested to be too difficult to perform in natural situations (but see Healy \& Hurly, 2013; Janmaat et al., 2013a, b, 2014; Sirianni et al., 2015 for nice examples of how it could be done). On the other side, they have the drawbacks that the chimpanzees have lived for years in speciesinappropriate environmental conditions and the cognitive tasks used to test them often have low ecological validity. On the other side, the natural observations have the huge advantage of the chimpanzees living in species-appropriate conditions with high ecological validity. To some, the advantage of captive experiments weighs high enough to accept the drawbacks (Povinelli, 2000; Tomasello \& Call, 1997, 2008). For others, the drawbacks are high enough to require an effort in finding new ways to perform experiments in the natural living conditions (see Byrne \& Bates, 2011; Healy \& Hurly, 2013; Sirianni et al., 2018).

\section{Table 2}

Comparison of the Conditions in Human-Chimpanzee Comparisons when Performed in an Experimental Captive Setting or in an Observational Field Setting*

\begin{tabular}{|l|l|l|l|}
\hline & Ontogeny & Procedure & Cognitive Task \\
\hline $\begin{array}{l}\text { Experiments in } \\
\text { captivity }\end{array}$ & Species inappropriate ${ }^{1}$ & Similar $^{2}$ & Low ecological validity \\
\hline $\begin{array}{l}\text { Experiments in } \\
\text { nature }\end{array}$ & Species appropriate & Similar & Medium ecological validity $^{4}$ \\
\hline Observational & Species appropriate & Spontaneous & \\
\hline
\end{tabular}

*after Byrne \& Bates, 2011; Healy \& Hurly, 2013; Leavens et al., 2019

${ }^{1}$ As a rule the animal species has grown up in an artificial captive setting very different from the evolutionary-relevant ecological conditions of the species, while the human individuals used in the comparison have grown up with their biological parents in family-appropriate conditions.

2 "Similar" in the sense that the conditions are not the same but are as similar as possible taking in account the specificity of the two species compared (Tomasello \& Call, 2008).

3 "Spontaneous" in the sense that it was the animal subject that decided when-where-what task it is performing, while the human subjects were mostly still tested in a temporary laboratory conditions (temporary as humans always lived outside of the laboratory, entering it only for the duration of the tests).

${ }^{4}$ Experiments in nature usually try to reproduce natural occurring challenges but use artificial procedures decreasing the ecological validity, like playback experiments with loudspeakers (e.g., Cheney \& Seyfarth, 1990), or providing hammers with artificial weight (Sirianni et al., 2018; Visalberghi et al., 2009).

\section{What in Ecology is Important for Cognition?}

In my view, the central issue is that, for different disciplines, the meaning of 'ecology' differs considerably, and this is at the base of many misunderstandings in some of the scientific debates about cognition. The main argument for taking recent results from captive experiments seriously is that today's captive living conditions have been tremendously improved since the 1950s, when they were quite detrimental to the subjects. It is certainly true that captive living conditions have improved for the animals, even if further improvement is still possible (Bloomsmith et al., 2019). If modern captive living conditions with some levels of enrichment, compared to the 1950s, has led to some reduction of stereotypic behaviors, abnormal behaviors are still observed in $37.1 \%$ to $100 \%$ of the captive chimpanzees (Bloomsmith et al., 2019). But this argument misses the point: understanding the effect of ecology on cognition is not only a question of welfare, but much more a question of "what are the evolutionary-relevant ecological conditions that selected for the emergence of chimpanzees?"

In Table 3, I summarize some of the key ecological parameters in the life of wild chimpanzees that contributed to the development of their cognitive abilities and search for the equivalent in captive conditions. Chimpanzees spend about $22 \%$ of the day light time searching for food and $45 \%$ of the time eating (Boesch \& Boesch-Achermann, 2000; Goodall, 1986). A chimpanzee territory is about 20 to 40 
$\mathrm{km}^{2}$ wide, which is quite larger than the average of $12 \mathrm{~m}^{2}$ per individuals in American zoos (Kaiser, 2014). Finding ripe fruits, the preferred-food source of wild chimpanzees, is challenging, as these fruiting trees are often rare, widely spread out within the territory, i.e., out-of-sight, and fruit production of individual trees in the forest is irregular and unpredictable. Thus, each individual chimpanzee needs to develop elaborate and complex spatial abilities and long-term memory (Janmaat et al., 2013a, b; Normand \& Boesch, 2009; Normand et al., 2009). Therefore, the energetic investment and cognitive challenges to find food are of utmost importance in the life of a chimpanzee (Janmaat et al., 2016, Table 3). Furthermore, chimpanzees in the wild eat not only ripe fruits, but also different species of insects and nuts that require often using tools to access them (Table 3). Taï chimpanzees used natural hammers to crack nuts on average for over one hour and 15 min daily during the four months of the Coula nut season and regularly for an additional 6 months of the Panda and Parinari nut seasons (Boesch \& BoeschAchermann, 2000). Finally, all known chimpanzee populations hunt small mammal prey for meat: Remarkably important population differences have been observed in the frequency of hunts as well as in the level of group hunting observed (Boesch \& Boesch-Achermann, 2000; Goodall, 1986, Table 3). If some populations, like Bossou chimpanzees, hunt only small prey in an opportunistic individual way, others hunt in groups for arboreal monkeys, like in Gombe chimpanzees, while other have been seen to use coordinated complementary actions during group hunts, like in Taï chimpanzees. None of these behavioral traits is required to live in captive conditions and, following the conclusions from Table 2, we need to ask ourselves what effect this has on the development of cognition for the individuals living in captivity.

Further, chimpanzees possess a typical fission-fusion grouping pattern by which a large number of community members ranging from 25 to 125 individuals with many adult males and females are rarely together but always in small constantly changing parties (Boesch \& Boesch-Achermann, 2000; Goodall, 1968, 1986). Group size and fission-fusion have been suggested to play an important role in the development of brain structures and cognitive abilities (Aureli et al., 2008; Noonan et al., 2014; Sallet et al., 2011). In captive settings, average group size is of 4.6 individuals (range $=1-14$, Bloomsmith et al., 2019, Table 3) and they are constantly together, facilitating the understanding of social dynamics within the group. The social challenges are therefore significantly easier to solve in captivity than in the wild.

In addition, feeding competition in the wild reaches a completely different dimension, occurring not only between group members with high-ranking individuals having an advantage, but also with the many other species in their environment that feed on the same fruits (Janmaat et al., 2014, 2016). Taï chimpanzees can travel at night to start to eat in popular fruiting trees before competing species arrive (Janmaat et al., 2014). In contrast, in captive settings, food is always plentiful and provided ready-to-eat to all individuals. Finally, individuals in the wild are dependent upon one-another in the natural environment when facing predations by leopards or the constant pressure from neighboring chimpanzee communities (Boesch, 2009, 2012; Goodall, 1986; Mitani et al., 2000; Wilson et al., 2014).

The contrast between the conditions in captivity and in the wild (Table 3) combined with the growing consensus that environmental enrichment is necessary for the development of cognition (Table 1) suggests that the cognitive abilities documented in captivity will be representative for the species only under these special conditions, and any generalization to the whole of the species will be questionable.

Povinelli and his team's very detailed and precise experimental program was able to reveal many fascinating aspects of the cognition of his chimpanzee peer group (Penn \& Povinelli, 2007; Penn et al., 2008; Povinelli, 2000, 2012). They, however, seem to underplay the potential role of the exceptional conditions they provided to their peer group of chimpanzees and interpret their results as applying to chimpanzees in general. In their paper entitled "Darwin's mistake: Explaining the discontinuity between human and nonhuman minds," Penn et al. (2008) do not hesitate to claim in their abstract that:

Darwin was mistaken: the profound biological continuity between human and nonhuman animals masks an equally profound discontinuity between human and nonhuman minds. To wit, there is a significant discontinuity in the degree to which human and nonhuman animals are able to approximate the higher-order, systematic, 
relational capabilities of a physical symbol system. We show that this symbolicrelational discontinuity pervades nearly every domain of cognition and runs much deeper than even the spectacular scaffolding provided by language or culture alone can explain. (p. 109)

Noteworthy, they do not cite a single publication on wild chimpanzees in their paper and base all their conclusions on captive individuals living in atypical ecological conditions. From the wild chimpanzees' perspective, Povinelli's results are extremely important and fascinating, NOT because of his interpretation, but because they revealed so nicely some of the potential cognitive limitations of chimpanzees forced to live under such special artificial conditions (Figure 1).

Table 3

Cognitive Ecology of Chimpanzees Compared Between Wild and Captive Living Conditions

\begin{tabular}{|c|c|c|c|c|}
\hline & Wild & $\begin{array}{l}\text { Condition-dependent } \\
\text { cognition }\end{array}$ & Captive & $\begin{array}{l}\text { Condition-dependent } \\
\text { cognition }\end{array}$ \\
\hline Fruit Feeding & $\begin{array}{l}\text { - Fruit trees are about } 1.5 \text { to } 3 \mathrm{~km} \text { apart } \\
\text { - Fruit trees depleted after about } 1 \text { month } \\
\text { - Chimpanzees feed on at least } 8 \text { fruit } \\
\text { tree species per month } \\
\text { - Chimpanzees remember fruit } \\
\text { production between seasons } \\
\text { - Chimpanzees plan their daily travels } \\
\text { ahead }\end{array}$ & $\begin{array}{l}\text { - Flexible, complex } \\
\text { mental map } \\
\text { - Long-term memory } \\
\text { - Action planning }\end{array}$ & $\begin{array}{l}\text { Food prepared } \\
\text { and provided } \\
\text { daily by } \\
\text { caretakers }{ }^{1}\end{array}$ & No specific trait \\
\hline $\begin{array}{l}\text { Nut/Insect } \\
\text { Feeding }\end{array}$ & $\begin{array}{l}\text { - Insects embedded in nest } \\
\text { - Sticks allow for better extraction } \\
\text { - Optimal hammer selection to access } \\
\text { hard shelled nuts }\end{array}$ & $\begin{array}{l}\text { - Different tools } \\
\text { - Tool use } \\
\text { - Tool selection f } \\
\text { (function) }\end{array}$ & $\begin{array}{l}\text { Tools not } \\
\text { necessary }\end{array}$ & No specific trait \\
\hline Meat Feeding & $\begin{array}{l}\text { - Detection of prey } \\
\text { - Overcome prey escape behavior } \\
\text { - Meat sharing among group members } \\
\end{array}$ & $\begin{array}{l}\text { - Search for prey } \\
\text { - Group hunt } \\
\text { - Food sharing } \\
\end{array}$ & $\begin{array}{l}\text { Food prepared } \\
\text { and provided } \\
\text { daily }{ }^{1}\end{array}$ & No specific trait \\
\hline Social Life & $\begin{array}{l}\text { - Fission-fusion grouping pattern } \\
\text { - Multi-males, multi-females large } \\
\text { groups } \\
\text { - Coalitions and alliances frequent } \\
\text { - Male philopatry and female dispersal } \\
\text { - Maternal investment throughout } \\
\text { infancy and juvenile stage with } 75 \% \text { for } \\
\text { adolescent }\end{array}$ & $\begin{array}{l}\text { - Social learning from } \\
\text { mothers and expert } \\
\text { conspecifics } \\
\text { - Group-coordinated } \\
\text { behavior } \\
\text { - Social inhibition } \\
\text { regulation }\end{array}$ & $\begin{array}{l}\text { - Small stable } \\
\text { groups } \\
\text { - Human- } \\
\text { shaped } \\
\text { demography } \\
\text { - Maternal } \\
\text { investment } \\
\text { rare }^{3}\end{array}$ & $\begin{array}{l}\text { - Social learning } \\
\text { from humans }{ }^{4} \\
\text { - Some social } \\
\text { regulation } 4\end{array}$ \\
\hline $\begin{array}{l}\text { Predation / } \\
\text { Competition }\end{array}$ & $\begin{array}{l}\text { - Predation pressure from leopards } \\
\text { - Intergroup competition with possible } \\
\text { fatal encounters } \\
\text { - Cooperation to defend territory } \\
\text { - Direct and indirect interspecific feeding } \\
\text { competition for fruits and nuts }\end{array}$ & $\begin{array}{l}\text { - Helping and empathy } \\
\text { for injured } \\
\text { - Cooperative group } \\
\text { behavior } \\
\text { - Planning to avoid } \\
\text { competitors }\end{array}$ & $\begin{array}{l}\text { - No predator } \\
\text { - Limited } \\
\text { competition }\end{array}$ & $\begin{array}{l}\text { - Lower empathy } \\
\text { - No pressure for } \\
\text { Cooperation }{ }^{4}\end{array}$ \\
\hline
\end{tabular}

${ }^{1}$ In all captive settings, food is provided by keepers on a regular basis during the day, without the need for the individuals to search for food nor to prepare or extract the food before consumption, except in a few cases whenever honey or other liquids are provided with possibility to use small sticks. Providing stones, as used by Taï chimpanzees, would present a risk of injuries. All wild animals need to search all day long for their food.

${ }^{2}$ Human caretakers are deciding about the composition and size of the groups of chimpanzees in captivity. The criteria used may be partly based on avoiding inbreeding risks, and attempts to reproduce natural group composition are limited by the small size of captive groups and the fear of injuries when more than one adult male would be included (Bloomsmith et al., 2019).

${ }^{3}$ In 2010, about half of the infants in the chimpanzee groups in the Leipzig zoo used for cognitive studies were hand -reared (Tempelmann et al., 2011).

${ }^{4}$ Captive groups of chimpanzees present large variability in size (range $=1$ to 14 , Bloomsmith et al., 2019) and composition, so that variations in the social effect should be expected. For example, larger groups or/and dominance in macaques favor neural circuit activity in regions known to play a role in social cognition (Sallet et al., 2011). 
Take the notion of connectivity or contact studied by Povinelli and his team. In a famous series of experiments, he placed chimpanzee subjects in front of a food they could acquire only by pulling at a handle or rope either placed in proximity to the food or connected with it. His peer-group chimpanzees performed often at chance-level selecting equally the connected or not-connected food. Imagine these same chimpanzees in a tree $40 \mathrm{~m}$ above the ground! What would happen if they jumped on a dead branch not connected to the tree trunk or on a far too thin branch given their weight? How could such a chimpanzee try to capture a monkey that runs and jumps full-speed between trees to escape?

Similarly, Povinelli wrote a book about his peer-group chimpanzees' notion of weight and their limitations in generalizing and understanding it (Povinelli, 2012). How would such a chimpanzee be able to crack nuts in the African forest where so many different potential "hammers" are found, of which only a small minority are functional (Boesch \& Boesch, 1984; Sirianni et al., 2015, 2018). Not only can Taï chimpanzees appreciate the need to adapt the weight of the hammer to the hardness of the nuts to crack, but they do so by selecting a hammer purely by looking at it and were not observed to manipulate it before use (Sirianni et al., 2018). Furthermore, they are not only able to select weight correctly, but at the same time select the size and hardness of the hammer conditional upon the distance they will need to transport it to the anvil where they intend to crack the nuts (Sirianni et al., 2015). Thereby, they demonstrated an uncanny ability to evaluate the unseen properties of tools. Sure, Taï chimpanzees grew up in an environment where processing nuts to eat them is essential for many months of the year, and they saw their mothers do so each year. That is a different world from the one that shaped the cognition of Povinelli's chimpanzees.

Povinelli's chimpanzees had difficulties distinguishing between a human with a bucket on the head from one with his visible eyes. His chimpanzees were seen to beg for food equally frequently to both of them! On the other side, wild chimpanzees seem especially sensitive to the gaze of social group members, although this has not been studied systematically in nature. For example, a low-ranking chimpanzee will greet a higher-ranking individual as long as the dominant acknowledges his submission with a peaceful gaze (and not with a head movement). If, however, the dominant refuses to look at him, the low-ranking individual will invariably start to scream (Boesch, personal observation; Goodall, 1968). Even hamadryas baboons know the importance of the eyes, when a subadult male would place himself precisely so that a dominant male could neither see him, nor see what he was doing though he could see the female he was grooming (Kummer, 1971). How would one of Povinelli's chimpanzees fare in such a social environment?

These examples illustrate how condition-dependent cognition could be affected by the conditions of life experienced. Besides the brain structural changes resulting from living in a wild environment, we should expect from the observations made by neuroscientists that the living conditions of Povinelli's group will lead to cognitive limitations. The great value of Povinelli's work with his seven peer-group chimpanzees is paralleled with some other psychology projects like the one on chimpanzees in the Leipzig zoo that originally came from a medical research center in the Rijswijk, Netherlands, where they have been subject to invasive experiments (Tempelmann et al., 2011). Once settled in Leipzig zoo, the chimpanzees experienced a better social life with 18 group members including nine adult females and one adult male, and they had access to one of the largest enclosures for a zoo in Europe. Intriguingly, the Leipzig chimpanzees were able to understand the notion of connectivity between objects but still not the notion of intactness of a tool (Herrmann et al., 2008). These observations and others from more captive groups with known life histories will allow documenting more precisely the factors leading to such limitations in the development of different cognitive abilities.

\section{Wild Side of Chimpanzee Cognition}

Development psychology is an important branch of psychology that directly addresses the effects of different experiences at different stages of life on the development of cognition. To do so, developmental psychologists have adopted a complex thinking on cognition and try to understand the different factors that contribute in humans to the development of cognition (Carpendale \& Lewis, 2004; 
Hackman \& Farah, 2009; Lewis et al., 2009; Noble et al., 2015; Olser et al., 2012). It seems, for biologists, awkward that some comparative psychologists seemed to have abandoned all the knowledge of developmental psychology and adopted a much more simplistic view on cognition. I am not suggesting that chimpanzees are humans and that all of development psychology applies to chimpanzees. I am simply stressing that chimpanzees are our closest living relative, that less than $1.4 \%$ of genetic differences exist between the two, and that we have been on distinct evolutionary branches for only about 6 million years. This should make it clear that we share more similarities than exist between chimpanzees and macaques, for example, and as scientists, we need to consider seriously the hypothesis that living conditions during ontogeny affect the development of cognition.

The experimental approach prevailing in comparative psychology should not mask the fact that, by controlling too many parameters, one directly influences the result of the comparison. Daniel Povinelli conceived his project with the aim of performing many very detailed and patiently conceived experiments; however, by doing so, he directly influenced the development of the cognition of his study subjects. This was done by limiting access to many factors known to importantly contribute to cognitive development (Allen, 2002; Bulloch et al., 2008; Furlong et al., 2008; Yocom \& Boysen, 2011).

Daniel Povinelli's detailed and thorough research will remain an essential landmark for understanding chimpanzee cognitive diversity when exposed to different captive living conditions. Once more detailed studies on the cognition of wild chimpanzees become available, more precise comparisons will be possible about the evolutionary-relevant ecological conditions that selected for the emergence of chimpanzees in general.

\section{References}

Allen, C. (2002). A skeptic's progress. Biology and Philosophy, 17, 695-702.

Anderson, M. (2010). Neural reuse: A fundamental organizational principle of the brain. Behavioral and Brain Sciences, 33, 245-313.

Anderson, M. (2016). Précis of after phrenology: Neural reuse and the interactive brain. Behavioral and Brain Sciences, 39, Article e120.

Anderson, M., Kinnison, J., \& Pessoa, L. (2013). Describing functional diversity of brain regions and brain networks. Neurolmage, 73, 50-58.

Aureli, F., Schaffner, C., Boesch, C., Bearder, S., Call, J., Chapman, C., Connor, R., Fiore, A., Dunbar, R., Henzi, P., Holekamp, K., Korstjens, A., Layton, R., Lee, P., Lehmann, J., Manson, J., Ramos-Fernandez, G., Strier, K., \& van Schaik, C. (2008). Fission-fusion dynamics: New research frameworks. Current Anthropology, 49, 627-654.

Barrett, L., Henzi, P., \& Rendall, D. (2007). Social brains, simple minds: Does social complexity really require cognitive complexity. Philosophical Transcriptions of the Royal Society, Series B, 362, 561-575.

Birkett, L., \& Newton-Fisher, N. (2011). How abnormal is the behavior of captive, zoo-living chimpanzees? PLoS One, 6, Article e20101.

Bloomsmith, M., Clay, A., Lambeth, S., Lutz, C., Breaux, S., Lammey, M., Franklin, A., Neu, A., Perlman, J., Reamer, L., Mareno, M., Schapiro, S., Vazquez, M., \& Bourgeois, S. (2019). Survey of behavioral indices of welfare in research chimpanzees (Pan troglodytes) in the United States. Journal of the American Association for Laboratory Animal Science, 58, 160-177.

Boesch, C. (2007). What makes us human (Homo sapiens)? The challenge of cognitive cross-species comparison. Journal of Comparative Psychology, 121, 227-240.

Boesch, C., \& Boesch-Achermann, H. (2000). The chimpanzees of the Taï forest: Behavioural ecology and evolution. Oxford University Press.

Bogart, S., Bennett, A., Schapiro, S., Reamer, L., \& Hopkins W. (2014). Different early rearing experiences have long-term effects on cortical organization in captive chimpanzees (Pan troglodytes). Developmental Science, $17,161-174$.

Buchanan, K., Grindstaff, J., \& Pravosudov, V. (2014). Condition dependence, developmental plasticity, and cognition: Implications for ecology and evolution. Trends in Ecology and Evolution, 28, 290-296.

Bulloch, M., Boysen, S., \& Furlong, E. (2008). Visual attention and its relation to knowledge states in chimpanzees, Pan troglodytes. Animal Behaviour, 76, 1147-1155. 
Byrne, R., \& Bates, L. (2011). Cognition in the wild: Exploring animal minds with observational evidence. Biology Letters, 7, 619-622.

Cantalupo, C., Oliver, J., Smith, J., Nir, T., Taglialatela, J., \& Hopkins, W. (2009). The chimpanzee brain shows human-like perisylvian asymmetries in white matter. European Journal of Neuroscience, 30, 431-438,

Carpendale, J., \& Lewis, C. (2004). Constructing an understanding of mind: The development of children's social understanding within social interaction. Behavioral and Brain Sciences, 27, 79-151.

Cheney, D., \& Seyfarth, R. (1990). How monkeys see the world: Inside the mind of another species. Chicago University Press.

Cheney, D., \& Seyfarth, R. (2007). Baboon metaphysics: The evolution of a social mind. The University of Chicago Press.

Clay, Z., \& de Waal, F. (2013). Development of socio-emotional competence in Bonobos. Proceedings of the National Academy of Sciences of the United States of America, 110, 18121-18126.

Conti, G., Hansman, C., Heckman, J., Novak, M., Ruggiero, A., \& Suomi, S. (2012). Primate evidence on the late health effects of early-life adversity. Proceedings of the National Academy of Sciences, 109, 8866-8871.

DeCasien, A., Williams, S., \& Higham, J. (2017). Primate brain size is predicted by diet but not sociality. Nature Ecology and Evolution, 1, Article 0112.

Draganski, B., Gaser, C., Busch, V., Schuierer, G., Bogdahn, U., \& May, A. (2004). Changes in grey matter induced by training. Nature, 427, 311-312.

Erickson, K., Prakash, R., Voss, M., Chaddock, L., Hu, L., Morris, K., White, S., Wójcicki, T., McAuley, E., \& Kramer, A. (2009). Aerobic fitness is associated with hippocampal volume in elderly humans. Hippocampus, 19, 1030-1039.

Esmaeilzadeh, S., Hartman, E., Farzizadeh, R., Azevedo, L., Kalantari, H., Dziembowsak, I., Narimani, M., \& Abravesh, A. (2018). Association between physical fitness and cognitive performance in 19-24 year old males. Biology of Sport, 35, 355-362.

Feng, X., Wanga, L., Yanga, S., Qin, D., Wanga, J., Li, C., Lv, L., Ma, Y., \& Hu, X. (2011). Maternal separation produces lasting changes in cortisol and behavior in rhesus monkeys. Proceedings of the National Academy of Sciences of the United States of America, 108, 14312-14317.

Furlong, E., Boose, K., \& Boysen, S. (2008). Raking it in: The impact of enculturation on chimpanzee tool use. Animal Cognition, 11, 83-97.

Garner, B., Wood, S., Pantelis, C., \& Buuse, M. (2007). Early maternal deprivation reduces prepulse inhibition and impairs spatial learning ability in adulthood: No further effect of post-pubertal chronic corticosterone treatment. Behavioural Brain Research, 176, 323-332.

Gelfo, F., Mandolesi, L., Serra, L., Sorrentino, G., \& Caltagirone, D. (2018). The neuroprotective effects of experience on cognitive functions: Evidence from animal studies on the neurobiological bases of brain reserve. Neuroscience, 370, 218-235.

González-Forero, M., \& Gardner, A. (2018). Inference of ecological and social drivers of human brain-size evolution. Nature, 557, 554-557.

Goodall, J. (1968). Behaviour of free-living chimpanzees of the Gombe Stream area. Animal Behaviour Monograph, $1,163-311$.

Goodall, J. (1986). The chimpanzees of Gombe: Patterns of behavior. The Belknap Press of Harvard University Press.

Gray, J., \& Thompson, P. (2004). Neurobiology of intelligence: Science and ethics. Nature Reviews, 5, 471-482.

Hackmann, D., \& Farah, M. (2009). Socioeconomic status and the developing brain. Trends in Cognitive Science, $13,65-73$.

Haenggi, J., Langer, N., Lutz, K., Birrer, K., Merillat, S., \& Jaencke, L. (2015). Structural brain correlates associated with professional handball playing. PLoS One, 10, Article e0124222.

Han, Y., Yang, H., Lv, Y., Zhu, C., He, Y., Tang, H., Gong, Q., Luo, Y., Zang, Y., \& Dong, Q. (2009). Gray matter density and white matter integrity in pianists' brain: A combined structural and diffusion tensor MRI study. Neuroscience Letters, 459, 3-6.

Healy, S., \& Hurly, T. (2013). What hummingbirds can tell us about cognition in the wild. Comparative Cognition and Behavior Reviews, 8, 13-28.

Healy, S., Bacon, I., Haggis, O., Harris, A., \& Kelley, L. (2008). Explanations for variation in cognitive ability: Behavioural ecology meets comparative cognition. Behavioural Processes, 80, 288-294.

Herrmann, E., Wobber, V., \& Call, J. (2008). Great apes' (Pan troglodytes, Pan paniscus, Gorilla gorilla, Pongo pygmaeus) understanding of tool functional properties after limited experience. Journal of Comparative Psychology, 122, 220-230. 
Hopkins, W., Lyn, H., \& Cantalupo, C. (2009). Volumetric and lateralized differences in selected brain regions of chimpanzees (Pan troglodytes) and bonobos (Pan paniscus). American Journal of Primatology, 71, 988997.

Iwaniuk, A., Lefebvre, L., \& Douglas, W. (2009). The comparative approach and brain-behaviour relationships: A tool for understanding tool use. Canadian Journal of Experimental Psychology, 63, 150-159.

Jaeggi, S., Bushkuehl, M., Jonides, J., \& Perrig, W. (2008). Improving fluid intelligence with training on working memory. Proceedings of the National Academy of Sciences of the United States of America, 105, 68296833.

Jaencke, L., Koeneke, S., Hoppe, A., Rominger, C., \& Haenggi, J. (2009). The architecture of the golfer's brain. PLoS One, 4, Article e4785.

Janmaat, K., Ban, S., \& Boesch, C. (2013a). Chimpanzees use long-term spatial memory to monitor large fruit trees and remember feeding experiences across seasons. Animal Behavior, 86, 1183-1205.

Janmaat, K., Ban, S., \& Boesch, C. (2013b). Tai chimpanzees use botanical skills to discover fruit: What we can learn from their mistakes. Animal Cognition, 16, 851-860.

Janmaat, K., Boesch, C., Byrne, R., Chapman, C., Gone Bi, Z., Head, J., Robbins, M., Wrangham, R., \& Polansky, L. (2016). Spatio-temporal complexity of chimpanzee food: How cognitive adaptations can counteract the ephemeral nature of ripe fruit. American Journal of Primatology, 78, 626-645.

Janmaat, K., Polansky, L., Ban, S. D., \& Boesch, C. (2014). Wild chimpanzees plan their breakfast time, type, and location. Proceedings of the National Academy of Sciences of the United States of America, 111, 1634316348.

Jednorog, K., Altarelli, I., Monzalvo, K., Fluss, J., Dubois, J., Billard, C., Dehaene-Lambertz, G., \& Ramus, F. (2012). The influence of socioeconomic status on children's brain structure. PLoS ONE, 7, e42486.

Kaiser, J. (2014, April 4). NIH puts squeeze on chimpanzee living space. Science.

Kozorovitski, Y., Gross, C., Kopil, C., Battaglia, L., McBreen, M., Stranahan, A., \& Gould, E. (2005). Experience induces structural and biochemical changes in the adult primate brain. PNAS, 102, 17478-17482.

Kummer, H. (1971). Primate societies: Group techniques of ecological adaptation. Aldine.

Leavens, D., Bard, K., \& Hopkins, W. (2019). The mismeasure of ape social cognition. Animal Cognition, 22, 487504.

Leeuwen, E., Mulenga, I., \& Chidester, D. (2014). Early social deprivation negatively affects social skill acquisition in chimpanzees (Pan troglodytes). Animal Cognition, 17, 407-414.

Lefebvre, L., Nocilakakis, N., \& Boire, D. (2002). Tools and brains in birds. Behaviour, 139, 939-973.

Lewis, C., Koyasu, M., Oh, S., Ogawa, A., Short, B., \& Huang, Z. (2009). Culture, executive function, and social understanding. New Directions for Child and Adolescent Development, 123, 69-85.

Mars, R., Sallet, J., Neubert, F., \& Rushworth, M. (2013). Connectivity profiles reveal the relationship between brain areas for social cognition in human and monkey temporoparietal cortex. PNAS, 110, 10806-10811.

May, A. (2011). Experience-dependent structural plasticity in the adult human brain. Trends in Cognitive Sciences, $15,475-482$.

Middleton, L., Mitnitski, A., Fallah, N., Kirkland, S., \& Rockwood, K. (2008). Changes in cognition and mortality in relation to exercise in late life: A population based study. PLOS ONE, 3, Article e3124.

Mitani, J., Merriwether, A., \& Zhang, C. (2000). Male affiliation, cooperation and kinship in wild chimpanzees. Animal Behaviour, 59, 885-893.

Mora, F., Segovia, G., \& Arco, A. (2007). Aging, plasticity and environmental enrichment: Structural changes and neurotransmitter dynamics in several areas of the brain. Brain Research Reviews, 55, 78-88.

Navarrete, A., Reader, S., Street, S., Whalen, A., \& Laland, K. (2016). The coevolution of innovation and technical intelligence in primates. Philosophical Transactions of the Royal Society B, 371, 20150186.

Neubert, F., Mars, R., Sallet, J., \& Rushworth, M. (2015). Connectivity reveals relationship of brain areas for reward-guided learning and decision making in human and monkey frontal cortex. Proceedings of the National Academy of Sciences of the United States of America, 112, E2695-E2704.

Noble, K., Houston, S., Brito, N., Bartsch, H., Kan, E., Kuperman, J., Akshoomoff, N., Amaral, D., Bloss, C., Libiger, O., Schork, N., Murray, S., Casey, B., Chang, L., Ernst, T., Frazier, J., Gruen, J., Kennedy, D., Van Zijl, P., Mostofsky, S., ...Sowell, E. (2015). Family income, parental education and brain structure in children and adolescents. Nature Neuroscience, 18, 773-780.

Noonan, M., Sallet, J., Mars, R., Neubert, F., O’Reilly, J., Andersson, J., Mitchelee, A., Bell, A., Miller, K., \& Rushworth, M. (2014). A neural circuit covarying with social hierarchy in macaques. PLoS Biology, 12, Article e1001940. 
Normand, E., Ban, S., \& Boesch, C. (2009). Forest chimpanzees (Pan troglodytes verus) remember the location of numerous fruit trees. Animal Cognition, 12, 797-807.

Normand, E., \& Boesch, C. (2009). Sophisticated Euclidian maps in forest chimpanzees. Animal Behaviour, 77, 1195-1201.

Novak, M. \& Harlow, H. (1975). Social recovery of monkeys isolated for the first year of life: I. Rehabilitation and therapy. Developmental Psychology, 11, 453-465.

Olser, M., Avlund, K., \& Mortensen, E. (2012). Socio-economic position early in life, cognitive development and cognitive change from young adulthood to middle age. European Journal of Public Health, 23, 974-980.

Oomen, C., Soeters, H., Audureau, N., Vermunt, L., van Hasselt, F., Manders, E., Joëls, M., Krugers, H., \& Lucassen, P. (2011). Early maternal deprivation affects dentate gyrus structure and emotional learning in adult female rats. Psychopharmacology, 214, 249-260.

Penn, D., Holyoak, K., \& Povinelli, D. (2008). Darwin's mistake: Explaining the discontinuity between human and nonhuman minds. Behavioral and Brain Sciences, 31, 109-178.

Penn, D., \& Povinelli, D. (2007). On the lack of evidence that non-human animals possess anything remotely resembling a 'theory of mind.' Philosophical Transactions of the Royal Society B, 362, 731-744.

Peper, J., Brouwer, R., Boomsa, D., Kahn, R., \& Hulshoff Pol, H. (2007). Genetic influences on human brain structure: A review of brain imaging studies in twins. Human Brain Mapping, 28, 464-473.

Pope, S., Taglialatela, J., Skiba, S., \& Hopkins, W. (2018). Changes in frontoparietotemporal connectivity following do-as-I-do imitation training in chimpanzees (Pan troglodytes). Journal of Cognitive Neuroscience, 30, 421-431.

Povinelli, D. (2000). Folk physics for apes: The chimpanzee's theory of how the world works. Oxford University Press.

Povinelli, D. (2012). World without weight: Perspectives on an alien mind. Oxford University Press.

Pravosudov, V., \& Omanska, A. (2005). Dominance-related changes in spatial memory are associated with changes in hippocampal cell proliferation rates in mountain chickadees. Journal of Neurobiology, 62, 31-41.

Pravosudov, V., \& Roth, T. (2013). Cognitive ecology of food hoarding: The evolution of spatial memory and the hippocampus. Annual Review of Ecology, Evolution and Systematic, 44, 173-193.

Quallo, M., Price, C., Ueno, K., Asamizuyad, T., Cheng, K., Lemon, N., \& Iriki, A. (2009). Gray and white matter changes associated with tool-use learning in macaque monkeys. Proceedings of the National Academy of Sciences of the United States of America, 106, 18379-18384.

Rosati, A. (2017). Foraging cognition: Reviving the ecological intelligence hypothesis. Trends in Cognitive Sciences, 21, 691-702

Rosati, A., Rodriguez, K., \& Hare, B. (2014). The ecology of spatial memory in four lemur species. Animal Cognition, 17, 947-961.

Sallet, J., Mars, R., Noonan, M., Andersson, J., O ’Reilly, J., Jbabdi, S., Croxson, P., Jenkinson, M., Miller, K., \& Rushworth, M. (2011). Social network size affects neural circuits in macaques. Science, 334, 697-700.

Sallet, J., Mars, R., Noonan, M., Neubert, F., Jbabdi, S., O’Reilly, J., Filippini, N., Thomas, A., \& Rushworth, M. (2013). The organization of dorsal frontal cortex in humans and macaques. The Journal of Neuroscience, $33,12255-12274$.

Salvanes, A., Moberg, O., Ebbesson, Nilsen, T., Jensen, K., \& Braithwaite, V. (2013). Environmental enrichment promotes neural plasticity and cognitive ability in fish. Proceedings of the Royal Society B, 280, 20131331.

Schrauf, C., Huber, L., \& Visalberghi, E. (2008). Do capuchin monkeys use weight to select hammer tools? Animal Cognition, 11, 413-422.

Sirianni, G., Mundry, R., \& Boesch, C. (2015). When to choose which tool: Multidimensional and conditional selection of nut-cracking hammers in wild chimpanzees. Animal Behaviour, 100, 152-165.

Sirianni, G., Wittig, R., Gratton, P., Mundry, R., Schüler, A., \& Boesch, C. (2018). Do chimpanzees anticipate an object's weight? A field experiment on the kinematics of hammer-lifting movements in the nut-cracking Taï chimpanzees. Animal Cognition, 21, 109-118.

Smulders, T., Gould, K., \& Leaver, L. (2010). Using ecology to guide the study of cognitive and neural mechanisms of different aspects of spatial memory in food-hoarding animals. Philosophical Transactions of the Royal Society B, 365, 883-900.

Suomi, S. J., \& Harlow, H. F. (1972). Social rehabilitation of isolate-reared monkeys. Developmental Psychology, 6 , 487-496.

Tempelmann, S., Kaminski, J., \& Liebal, K. (2011). Focus on the essential: all great apes know when others are being attentive. Animal Cognition, 14, 433-439. 
Thornton, A., \& Lukas, D. (2012). Individual variation in cognitive performance: Developmental and evolutionary perspectives. Philosophical Transactions of the Royal Society B, 367, 2773-2783.

Tia, B., Viaro R., \& Fadiga, L. (2018). Tool-use training temporarily enhances cognitive performance in long-tailed maca,ques (Macaca fascicularis). Animal Cognition, 21, 365-378.

Tomasello, M., \& Call, J. (1997). Primate cognition. Oxford University Press.

Tomasello, M., \&. Call, J. (2008). Assessing the validity of ape-human comparisons: A reply to Boesch (2007). Journal of Comparative Psychology, 122, 449-452.

Visalberghi, E., Addessi, E., Truppa, V. Spagnoletti, N., Ottoni, E., Izar, P., \& Fragaszy, D. (2009). Selection of effective stone tools by wild bearded capuchin monkeys. Current Biology, 19, 213-217.

van Praag, H. (2009). Exercise and the brain: Something to chew on. Trends in Neurosciences, 32, 283-290.

van Praag, H., Kempermann, G., \& Gage, F. (2000). Neural consequences of environmental enrichment. Nature Neuroscience, 1, 191-198.

Voss, M., Vivar, C., Kramer, A., \& van Praag, H. (2013). Bridging animal and human models of exercise-induced brain plasticity. Trends in Cognitive Sciences, 17, 525-544.

Wilson, M., Boesch, C., Fruth, B., Furuichi, T., Gilby, I., Hashimoto, C., Hobaiter, C., Hohmann, G., Itoh, N., Koops, K., Lloyd, J., Matsuzawa, T., Mitani, J., Mjungu, D., Morgan, D., Muller, M., Mundry, R., Nakamura, M., Pruetz, J., Pusey, A...Wrangham, R. (2014). Lethal aggression in Pan is better explained by adaptive strategies than human impacts. Nature, 513, 414-419.

Yocom, A., \& Boysen, S. (2011). Comprehension of functional support by enculturated chimpanzees Pan troglodytes. Current Zoology, 57, 429-440. 